\title{
Necessity of Development on New Types of Activated Carbons for Advanced Drinking Water Purification Technology
}

\author{
Ji-Il Kim, Young-Ha Kim, Dong-Il Jang, Ki-Ho Jung and Soo-Jin Park^ \\ Department of Chemistry, Inha University, 253 Nam-gu, Incheon 402-751, South Korea \\ ‘e-mail: sjpark@inha.ac.kr \\ (Received October 25, 2010; Accepted December 11, 2010)
}

\section{1. 서 론}

최근 국내의 산업화 및 공업화가 가속됨에 따라 주요 상수 원의 수질이 급속히 나빠지면서 강 하류지역의 수질이 3 급수 이하로 떨어져 일반적인 정수방법으로는 오염물질의 제거가 어렵고, 1989년 이후 중금속, trihalomethanes (THM), 페놀, 벤 젠 등 각종 수돗물 유기물질 오염사고가 다발하면서 낙동강을 원수로 하는 정수장에서 우선적으로 고도정수시설을 도입하게 되었다 [1]. 기존의 정수처리 시설은 응집침전, 여과, 염소처리 로 구성되어 있으며, 이를 청정한 원수의 처리를 목적으로 하 는 '재래식 정수처리 공정(conventional water treatment system; CWTS)'이라고 한다 [1]. 그러나 상수원으로 사용하고 있는 주 요하천이나 호수가 각종 생활용수, 공업폐수, 농업용수 등으로 질소, 인 성분이 과다하게 증가되어 부영양화를 가속시키고 있 으며, 각종 난분해성 물질이나 중금속 성분, 발암성물질 및 농 약, 비료성분은 미량으로도 인체에 치명적인 결과를 주기 때 문에 기존의 재래식 정수처리 공정만으로는 한계가 있으며, 고 도정수처리 시스템의 도입이 필수 불가결한 문제로 대두되고 있다 [2-4].

고도정수처리 기술(advanced drinking water purification technology)이란, 재래식 정수처리법으로는 대상 오염물질의 제거가 곤란한 수질의 목표달성을 위해 기존의 수처리 법에 용존물질의 제거방법을 추가 적용하는 수처리 법을 말한 다 $[5,6]$. 국내·외의 정수장에서는 오존산화 처리공정과 다양 한 유기오염물질들에 대해 우수한 흡착능을 가지는 활성탄소 를 이용하여 오염물질을 흡착·제거하는 입상활성탄소 또는 생 물활성탄소 여과공정을 시행 중이며 그 효과 및 적용 타당성 이 입증되어 매년 도입이 크게 증가하고 있는 추세이다 [7].

1988년 일본에서는 일본수도협회에 설치된 '고도정수시설 Guide line 작성 전문위원회'에서 고도정수 시설도입을 위한 Guide line을 작성하였는데, 이에 따르면 '고도정수시설은 통 상의 정수처리 방법으로는 충분히 대응할 수 없는 THM 전구 물질, 색도, 암모니아성 질소, 음이온 계면활성제 등의 처리를 목적으로 도입하는 활성탄소 처리 시설, 오존처리 시설 및 생 물처리 시설 등을 지칭한다, 라고 정의하고 있다 [8].

활성탄소(activated carbons)은 다공성 탄소재료로서 내부에 무수한 세공이 발달되어 있는데 세공의 층 내부 표면적이 현
저하게 크고, 또한 그 표면이 불순물에 대하여 친수성을 갖게 되기 때문에 피 흡착 물질로서의 용해성 성분의 제거는 용해 성 성분이 세공의 커다란 내부표면에 흡착함으로써 이루어지 게 된다 $[9,10]$.

활성탄소 처리설비는 코코넛 껍질이나, 석탄, 나무 등을 고 온에서 탄화시켜 만든 활성탄소의 내부에 무수한 세공을 이용 하여 흡착가능한 유해물질들은 제거하는 것으로서, 용해성 유 기물질, THM 전구물질, 맛-냄새물질, 농약성분 등의 미량 유 해물질을 제거할 목적으로 도입되었으며 주로 용해성 성분을 제거하는 기능을 가지고 있고 저농도의 용해성 성분의 제거수 단으로서 사용되고 있다 $[11,12]$.

고도정수처리에 있어 원수에 잔류염소 존재 시 이온교환수 지의 산화로 인해 파쇄(가교결합이 끊어짐)되기 때문에 효율 이 저하되고 압력손실이 증가하게 되므로 잔류염소농도는 $0.1 \mathrm{ppm}$ 이하로 유지관리 되어야 한다. 또한 원수 중 유기물 이 존재할 시에는 흡착 또는 이온교환반응에 의해 이온교환수 지가 오염되어 수세수의 사용량 증가, 처리수의 수질악화, 처 리수의 산성으로 변화, 이산화규소 $\left(\mathrm{SiO}_{2}\right)$ 의 조기누출 등 여러 가지 문제가 발생하게 되므로 처리한 수질의 화학적 산소요구 량(chemical oxygen demand, COD) 농도는 $1 \mathrm{ppm}$ 이하로 유 지하여야 한다. 따라서 활성탄소처리는 필수공정으로 선택되 어야 한다 [7].

현재까지 막분리와 고도산화기술이 주류인 고도정수처리 시 장은 최근 비약적인 높은 흡착능을 보이는 활성탄소의 적용이 증가하고 있어 세계시장은 급격한 확산 중에 있는 추세이다. 2007 2008년 사이 활성탄소 생산단가의 증가로 인하여, coal 로 만든 활성탄소의 가격이 $80 \%$ 의 증가를 보임에 따라 저가 활성탄소 개발에 대한 관심과 논의가 활발히 진행되고 있다. 최근 세계의 활성탄소 수요량은 9\%의 인상률을 보이며, 2014 년까지 약 17 억톤까지 증가할 것으로 예상된다 [13].

이런 급속한 고도정수처리용 활성탄소의 수요증가에 따라 원자재확보 및 생산기반이 취약한 우리나라가 세계 물시장에 서 어려움이 예상되는 바, 국내 물산업의 자생력을 키우기 위 해서는 그 핵심기술이라 할 수 있는 고도정수처리용 흡착제로 서 활성탄소의 대량생산을 지원할 수 있는 제작인프라를 시급 히 구축해야 하며 이를 중심으로 연구개발, 제작, 시험평가 기 관 협력체계를 구축하여 기술확산을 가속화시켜야 할 시점에 
Table 1. 입상활성탄소와 분말활성탄소의 선택 시 고려사항

\begin{tabular}{|c|c|c|c|}
\hline 구 & 항 목 & 입상활성탄소 & 분말활성탄소 \\
\hline \multirow{8}{*}{$\begin{array}{l}\text { 입상활성탄소 } \\
\text { 장점 }\end{array}$} & 주입방법 & 취급용이 (비산없음) & 취급곤란 (비산분진 발생) \\
\hline & 안전성 & $\begin{array}{l}\text { 원수의 농도가 급변하여도 } \\
\text { 즉시 유출수 영향없음 }\end{array}$ & 불연속 조업 \\
\hline & 처리공정의 연속일련화 & 연속적 향류 조업가능 & 불연속 조업 \\
\hline & 운전비용 & 적음 (교체기간이 길고 자동화) & 큼 (노동력에 의존) \\
\hline & 경제성 & 재생 가능하므로 경제적임 & 비 경제적 \\
\hline & 환경오염 & 흡착질을 연소 또는 회수하여 무해화 & 침전탄의 진훍화로 2차 오염 \\
\hline & 중수 누출 & 염려없음 & 계절영향 받음 \\
\hline & 조업 중단 & 입자 응결성 없으므로 문제없음 & 입자 응결 또는 투입 장치고장 등 문제 \\
\hline \multirow{3}{*}{$\begin{array}{l}\text { 분말활성탄소 } \\
\text { 장점 }\end{array}$} & $\begin{array}{c}\text { 고순도 } \\
\text { 처리 }\end{array}$ & $\begin{array}{l}\text { 흡착속도가 느리므로 여과조 } \\
\text { Type으로는 고순도 처리곤란 }\end{array}$ & $\begin{array}{c}\text { 흡착속도가 빠르므로 } \\
\text { Batch식으로 고순도 처리 }\end{array}$ \\
\hline & 처리시설 & $\begin{array}{c}\text { 여과조를 제작해야 함 } \\
\text { (초기 건설비가 큼) }\end{array}$ & $\begin{array}{c}\text { 간이식 저수조 이용가능 } \\
\text { (건설비가 작음) }\end{array}$ \\
\hline & $\begin{array}{l}\text { 간헐적 } \\
\text { 조업 }\end{array}$ & $\begin{array}{c}\text { 장기간 방치 시 미생물 발생, } \\
\text { 흡착능력의 저하우려 }\end{array}$ & $\begin{array}{l}\text { 사용 시마다 신탄을 } \\
\text { 사용하므로 문제없음 }\end{array}$ \\
\hline
\end{tabular}

와있다. 또한 포화활성탄소에 대한 폐기물 처리 문제 및 신탄 교체에 따른 경제적 부담을 고려해야 하며 경제적인 활성탄소 재생법과 그에 따른 재생탄의 효과에 대한 조사와 기존의 방 식을 넘어서 보다 효율적인 활성탄소 흡착처리시설에 대한 연 구가 필요한 실정이다.

따라서, 본 논문에서는 최근 각광받고 있는 활성탄소의 고 도정수처리 기술에 있어서의 그 필요성과 시장동향을 알아봄 으로써, 새로운 타입의 활성탄소개발 중요성을 다시 한번 각 인시키고, 이를 이용한 기타 응용방안 및 차후 발전방향에 대 하여 논의하고자 한다.
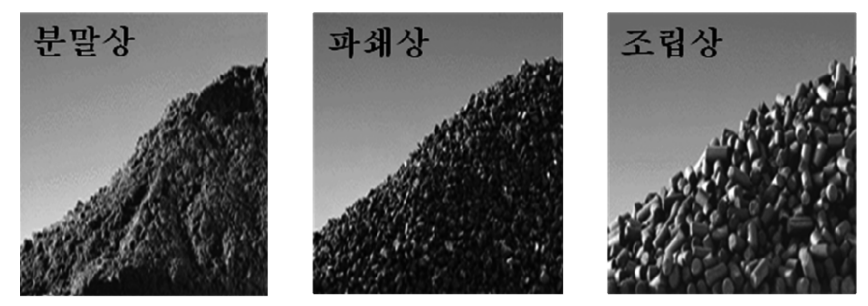

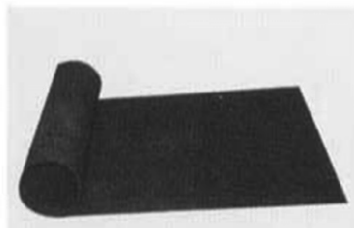

섬유상

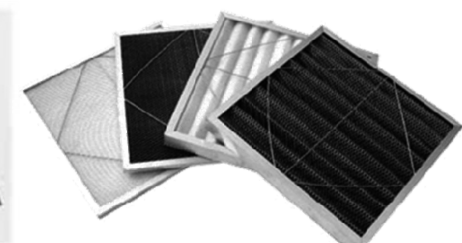

활성탄소섬유 필터
Fig. 1. 여러 가지 형태의 활성탄소.

\section{2. 본 론}

\section{1. 활성탄소}

활성탄소는 고도정수처리 및 유해물질의 제거 등에 사용되 는 흡착제로서, 공업용을 중심으로 탈취, 탈색, 정제, 촉매에도 사용되어 왔으며, 최근에는 에너지 저장용 소재로서의 연구 및 개발이 활발히 진행되고 있다. 활성탄소(활성탄소, 분말활성탄 소, 활성탄소섬유 등)은 보통 석탄계, 야자각계 등과 같은 활 성탄소와 핏치계, 폴리아크릴로나이트릴계, 페놀수지계, 셀룰 로오스계와 같은 활성탄소섬유 등이 있으며, 이들은 전구체를 물리/화학적인 방법을 통해 활성화시켜 제조한다 $[14,15]$.

최근 활성탄소가 흡착제로서의 우수한 성능 및 기능이 요구 됨에 따라, 흡착성능으로서는 활성탄소 본래의 물리적 흡착으 로서 불가능했던 산성가스 $\left(\mathrm{NO}_{\mathrm{x}}\right)$, 알칼리성 가스 $\left(\mathrm{NH}_{3}\right)$, 금속 수 은 등에 대한 제거능력이, 형태적인 면에서는 Fig. 1에 제시한 것과 같이 분말상, 입상, 파쇄상 등의 기존 형태 외에도 honeycomb상, 섬유상, 3 차원형상 등의 새로운 형태를 가진 활 성탄소가 개발되고 있다. 또한 활성탄소의 흡착능력을 향상시 키는 생물활성탄소(biological activated carbon)에 대한 기술개 발도 활발히 진행되고 있으며, 생물활성탄소는 입상활성탄소 에 미생물이 부착되도록 유도하여 활성탄소의 유기물흡착과 미생물에 의한 유기물질 분해 등의 두 가지 기능을 이용하는 기술로 알려져 있다 [16].

보통 수처리에 쓰이는 활성탄소는 세가지 종류가 있으며, 입 상활성탄소의 경우 활성탄소 코코넛 껍질이나 갈탄을 고온에 서 탄화시켜 만들어지는 입상활성탄소 내부의 무수한 세공에 


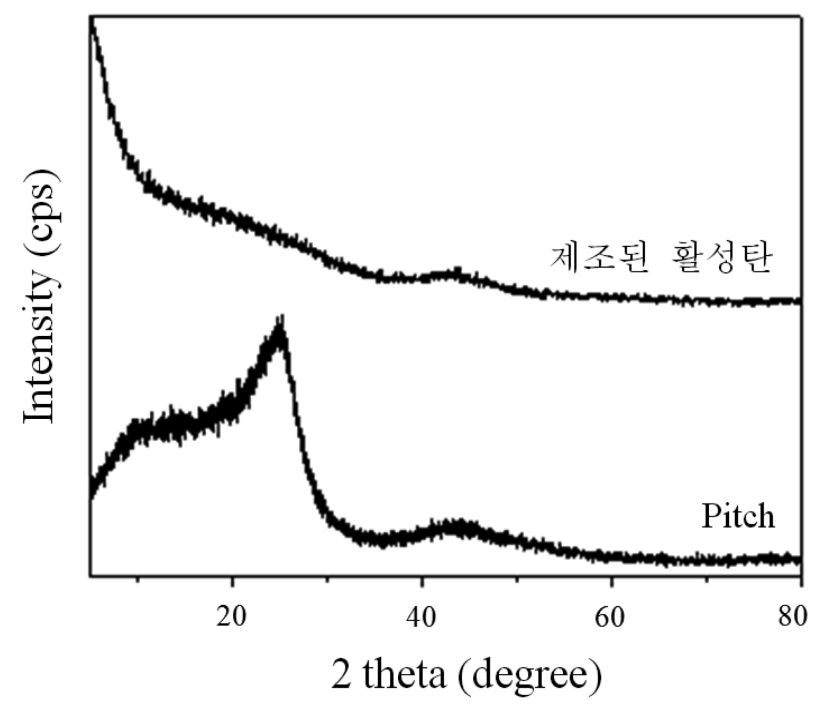

Fig. 2. Pitch와 Pitch로 제조한 활성탄소의 XRD 곡선.

흡착 가능한 유해물질 등을 흡착제거 목적으로 사용하고 있으 나, 재생주기가 6 12개월로 비교적 짧다는 단점이 있다. 생물 활성탄소의 경우 오존처리시설과 병행하여 입상활성탄소 시설 을 설치함으로써 오존처리시설에서 유기물질을 산화분해 시킨 후 입상활성탄소 내부의 세공에 성장한 미생물에 의해 유기물 질을 분해토록 하고 유해물질의 흡착도 이루어지게 할 수 있 으며, 재생주기가 2 3년 정도로 긴 편이다. 마지막으로 분말 활성탄소의 경우 입경이 작은 분말 형태의 활성탄소를 응집/ 침전 전 단계에 투입하여 유해물질을 흡착제거 하게 할 수 있 으며, 한번 사용된 분말활성탄소는 재생사용이 곤란하다는 단 점이 있다. Table 1은 액상흡착에서 주로 사용하는 분말 및 입 상활성탄소의 적용분야를 나타낸 것이다. 각각의 활성탄소는 제조 방법 및 응용분야의 차이가 있기 때문에 흡착하려는 물 질에 따른 선택이 매우 중요하다.

활성탄소는 하나하나의 입자에 잘 발달된 무수한 미세공공 으로 이루어진 무정형의 탄소의 집합체이며, 그 미세공공 (micropore, mesopore, macropore)은 상호연결되는 무수한 통 로로 구성되어 넓은 내부표면적을 갖고 있으며, 이 표면적은 상대분자 크기에 따른 세공의 크기의 적합성과 함께 활성탄소 의 생명인 흡착능력을 좌우하게 된다. 활성탄소 $1 \mathrm{~g}$ 은 1,000 $\sim 1,600 \mathrm{~m}^{2}$ 의 대단히 넓은 비표면적을 갖고 있으며, 세공의 분 포는 $10 \AA$ 의 세공구조를 주로 하여 $150,000 \AA$ 로 존재하는 해 면상의 다공질 구조이다 [17]. 활성탄소의 결정구조를 알 수 있 는 X선 회절분석 (XRD)을 Fig. 2에 나타내었다 [15]. X선 회 절분석에서 보듯이 (002)면의 회절이 매우 넓기 때문에 활성 의 구조가 기본적으로 비결정적이고, 미세흑연의 주기적 적층 이 작은 것을 알 수 있다. 다만 고온처리에 의해서 (002)회절 피크는 순서대로 날카로워지기 때문에 미세흑연의 배향은 완 전히 무작위로 존재하는 것이 아닌, 근거리의 질서성이 존재 하는 것을 알 수 있다. 흡착제에 세공의 일반적인 분류법은
Table 2. IUPAC에 의한 세공분류

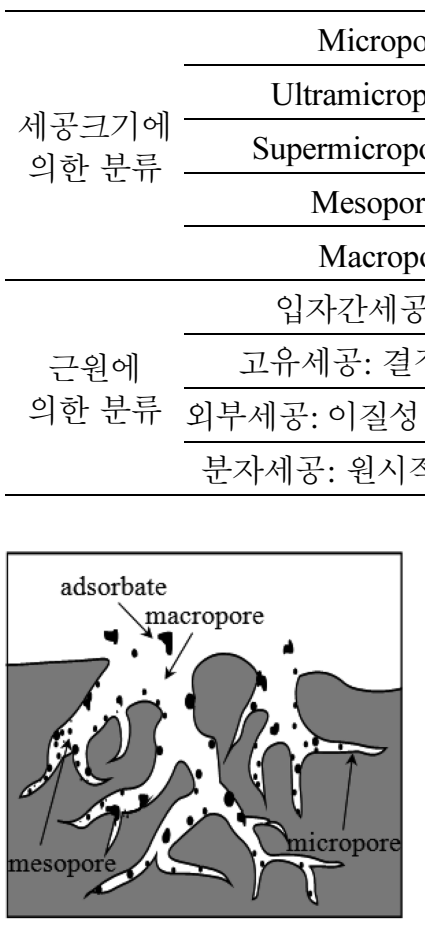

(a) 활성탄소

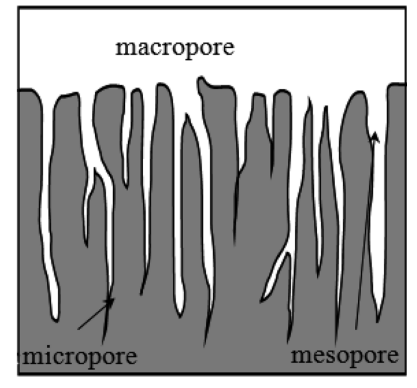

(b) 활성탄소섬유
Fig. 3. 활성탄소와 활성탄소섬유의 기공도.

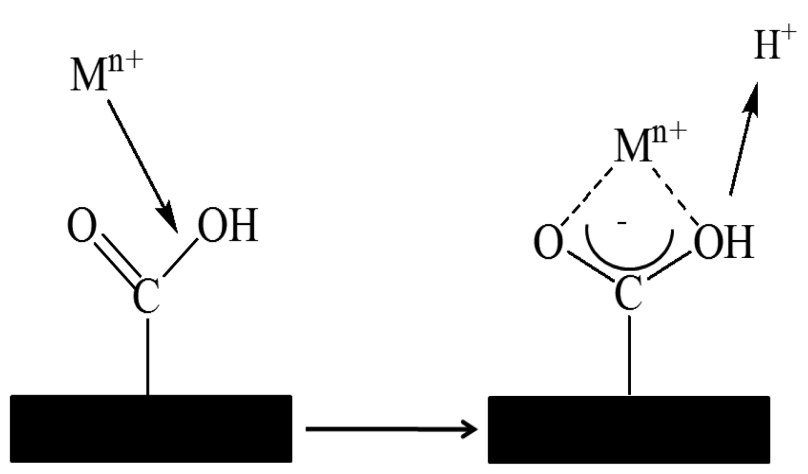

Fig. 4. 활성탄소 표면처리에 따른 중금속의 흡착효과 모식도.

IUPAC (International Union of Pure and Applied Chemistry) 규 정에 의해서 다음과 같은 크기별 그룹으로 나뉘어지며 Table 2에 나타내었다 [18].

활성탄소의 높은 흡착성은 세공구조에 의한 것임으로 그 구 조를 이해하는 것은 매우 중요하다. 세공구조를 기술하는 데 는 단위세공의 형상과 크기, 단위세공간의 망상구조가 필요하 지만, 보통은 세공경과 그 분포, 비표면적 및 세공용량이 사용 되고 있으며 Fig. 3에 표면세공 구조를 나타내었다 [17]. 이러 한 활성탄소 공극구조, 공극부피, 비표면적 등의 물리적 변화 와 화학적 변화를 수반할 수 있기 때문에 처리물질에 대한 활 
성탄소의 흡착능이 달라질 수 있다. Fig. 4는 표면처리에 의해 발달된 활성탄소의 카르복실기(carboxylic functional group)가 수처리 시 중금속을 효과적으로 흡착하는 반응 메커니즘의 예 를 보인 것이다 [19].

활성탄소는 소수성 물질이므로 액상에서 흡착질이 소수성이 클수록 흡착이 용이하다. 이는 물에 대한 용해도가 클수록 친 수성이므로 본질적으로 소수성인 활성탄소와 결합이 좋지 않 을 뿐만 아니라, 용해도가 크면 물과의 부분적인 수소결합이 이루어져 이가 흡착을 방해하기 때문이다. 이 밖에도 활성탄 소의 흡착능은 $\mathrm{pH}$ 영역대의 변화, 극성 및 비극성, 방향족 화 합물, 표면장력 등에 의해 변하는 성질을 갖고 있다 [20,21].

현재까지는 대부분의 유해물질 흡착제어기술은 수 수백 $\mu \mathrm{m}$ 단위의 분포를 갖는 입자들만이 포집, 제거되는 기술에 의해 주로 이루어져 왔으나, 최근 들어 나노기술이 광범위한 산업 분야에서의 오염원 방출의 이해와 제어를 통하여 기존 또는 새로운 환경오염 문제들의 발생과 대책마련에 대한 대안으로 제안되고 있다. 따라서 각종 오염물질에 대한 흡착 성능 및 효 율성을 향상시키기 위하여 극세공구조를 갖는 활성탄소소재의 제조 및 각종 표면처리 기술을 이용한 기능화기술이 필요하 다 [22,23].

그러나 고도정수처리에 사용되는 활성탄소는 흡착능력을 좌 우하는 비표면적이 작을 뿐만 아니라 표면에 오염물질에 대한 선택적 흡착능력을 가질 수 있는 표면관능기가 잘 발달되어 있지 않아 날로 그 종류가 다양화되는 각종 오염물질에 대한 흡착 혹은 분리능력이 떨어지는 단점을 가지고 있다. 그렇기 때문에 탄소재료의 습/건식 표면처리 기술을 이용하여 활성탄 소 표면에 오염물 선택형 관능기의 도입을 통한 성능개선 및 침윤된 금속과의 견착력을 증대시켜 고도정수처리용 흡착제의 성능을 개선하려는 노력이 각지에서 시행되고 있다. 탄소는 매 우 고온에서 제조되는 극한소재이기 때문에 표면에 산소 관능 기가 매우 부족하며, 이로 인해 극성을 가지는 금속에 대한 흡 착능이 상대적으로 작은 단점을 가진다. 때문에 탄소재료의 표 면처리는 본연의 흡착능을 이끌어 내는 핵심적인 처리기술로 대두되고 있다 [24,25].

현재 활성탄소 제조공정이 원료재료(석탄계, 식물성계)의 탄 화와 화학적 및 물리적 활성화법을 이용하는 것을 주된 과정 으로 하기 때문에 메탄(methane)가스와 여러 유기가스를 방출 하게 된다. 특히 활성탄소를 많이 생산하고 있는 스리랑카에 서는 활성탄소제조로 인하여 방출된 메탄 가스량이 2007년에 만 13만톤에 이를 정도로 매우 위험한 수준인 것으로 보고되 고 있다. 그만큼 제조공정에 있어서의 유해가스 방출을 최소 한으로 줄이기 위한 활성탄소제조의 새로운 공정 또한 필수불 가결한 시점에 이르렀다고 할 수 있을 것이다[26].

\section{2. 고도정수처리용 활성탄소 시장동향}

2.2.1. 시장의 특징

20 세기가 석유의 시대라면 21 세기는 블루다이아몬드인 물

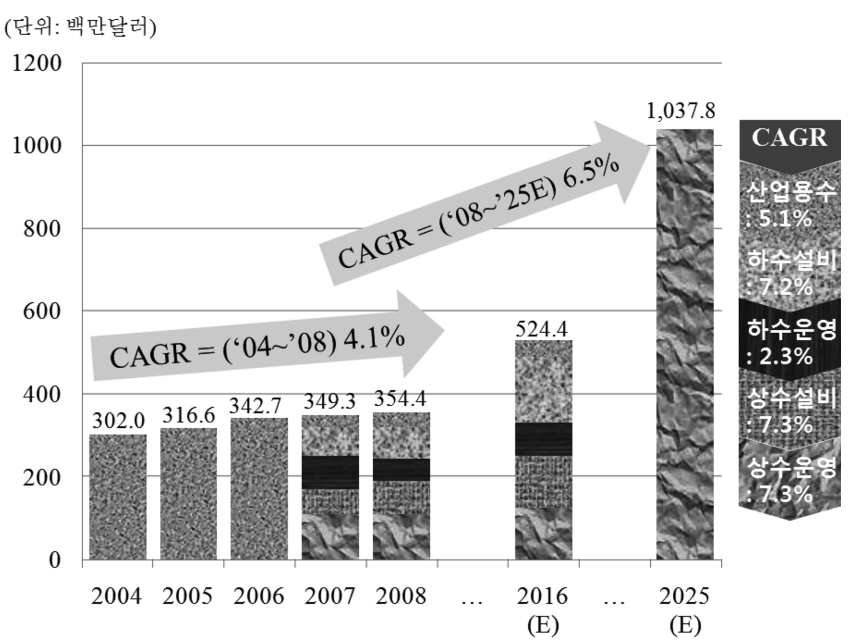

Fig. 5. 세계 물산업 시장규모 및 전망.

의 시대이며 2050년 세계의 수자원 수요는 2000년보다 $30 \%$ 증가한 약 $5,200 \mathrm{~km}^{3}$ 까지 증가할 것으로 예상되고 있다. 물 부 족 및 수질악화로 물산업이 급부상하고 있으며, 현 세계 물 시 장은 약 3,650억달러로서 향후 급속도로 시장규모가 확대될 것으로 전망인데 이를 Fig. 5에 나타내었다 [27]. 2007년 전세 계 물시장 규모는 3,650억달러 수준이며, 2016년에는 6,209억 달러 규모로 연평균 $6.1 \%$ 성장할 것으로 전망되고 있다. 부문 별 성장성은 수처리 사업이 연평균 $7.6 \%$ 로 가장 높으며, 이 가운데 멤브레인 방식 담수설비와 물 재사용 시장의 성장률이 각각 $10.8 \%, 14.5 \%$ 에 달해 성장세를 주도할 것으로 전망된다. 2004 년 기준으로 전 세계 하수처리율은 $42 \%$ 에 불과하였으며 과반 이상의 하수가 그대로 방류되어 지표수 및 지하수를 오 염시키고 있다. 세계 물 포럼(World Water Forum)에 따르면 현재 11 억명이 안전한 물을 마시지 못하고 있으며, 전쟁으로 인한 사망자의 10 배에 해당하는 매년 500 만명 이상이 수인성 질병으로 사망한다고 보고하고 있다 [28].

미국의 경제주간지 포춘(Fortune)은 2000년 5월 15 일자 기 사에서 "21세기에는 물산업은 블루골드(Blue Gold)로, 20세기 의 블랙골드(Black Gold)인 석유산업 만 큼이나 고성장할 것" 이라고 전망하였고, 이스마일 세라겔딘 세계은행 수석부총재 는 "20세기가 석유를 차지하기 위한 전쟁이었다면, 21세기는 물을 차지하기 위한 전쟁이다"라고 표현하고 있는 것에서 수 처리 기술의 중요성이 날로 증가한다는 것을 알 수 있다.

Global Water Intelligence (GWI)의 보고서에 의하면 [27], 향 후 멤브레인 시장의 성장률(19.6\%)은 화학처리제 시장의 성장 률(3.7\%)을 크게 상회할 것으로 전망되고 있으며, 특히 막분 리를 활용한 담수화 시스템은 기존 증류식에 비해 가격경쟁력 을 높기 때문에 고성장이 예상되어 2015년에 전체 담수화 장 비시장의 $60 \%$ 이상을 차지할 것으로 추정되고 있다. 또한 산 업재료를 전문으로 조사하는 기관인 Freedonia group의 최근 보고서에 따르면 [13], 미국의 활성탄소섬유의 수요는 현재의 
Table 3. 반도체 집적도에 따른 요구수질의 변화

\begin{tabular}{|c|c|c|c|c|c|c|}
\hline \multirow{2}{*}{ 항목 } & \multirow{2}{*}{ 단위 } & \multicolumn{5}{|c|}{ 반도체 집적도에 따른 요구수질의 변화 } \\
\hline & & $256 \mathrm{~K}$ & $1 \mathrm{M}$ & $4 \mathrm{M}$ & $16 \mathrm{M}$ & $64 \sim 128 \mathrm{M}$ \\
\hline 저항 & $\mathrm{M} \Omega \cdot \mathrm{cm}$ & $>17 \sim 18$ & $>18$ & $>18$ & $>18.1$ & $>18.2$ \\
\hline \multirow{4}{*}{$\begin{array}{l}\text { Particles } \\
(\mathrm{EA} / \mathrm{mL})\end{array}$} & $>0.2 \mu \mathrm{m}$ & \multirow{4}{*}{$<50$} & \multirow{4}{*}{$<10 \sim 20$} & \multirow{4}{*}{$<5$} & \multirow{4}{*}{$<5$} & \multirow{4}{*}{$<1$} \\
\hline & $>0.1 \mu \mathrm{m}$ & & & & & \\
\hline & $>0.05 \mu \mathrm{m}$ & & & & & \\
\hline & $>0.03 \mu \mathrm{m}$ & & & & & \\
\hline Bacteria & $\mathrm{EA} / 100 \mathrm{~mL}$ & $2 \sim 20$ & 0.01 & 0.005 & 0.001 & 0.001 \\
\hline TOC & $\mu \mathrm{g} / \mathrm{L}$ & $50 \sim 100$ & $30 \sim 50$ & $10 \sim 20$ & 2 & 1 \\
\hline $\mathrm{SiO}_{2}$ & $\mu \mathrm{g} / \mathrm{L}$ & 10 & $3 \sim 5$ & $1 \sim 3$ & 1 & 0.1 \\
\hline $\mathrm{Na}$ & $\mu \mathrm{g} / \mathrm{L}$ & - & 0.5 & 0.1 & 0.01 & 0.001 \\
\hline $\mathrm{Fe}$ & $\mu \mathrm{g} / \mathrm{L}$ & - & 0.5 & 0.1 & 0.01 & 0.001 \\
\hline $\mathrm{Zn}$ & $\mu \mathrm{g} / \mathrm{L}$ & - & 0.5 & 0.1 & 0.01 & 0.001 \\
\hline $\mathrm{Cu}$ & $\mu \mathrm{g} / \mathrm{L}$ & - & 0.5 & 0.1 & 0.01 & 0.001 \\
\hline $\mathrm{Cl}^{-}$ & $\mu \mathrm{g} / \mathrm{L}$ & - & 0.5 & 0.1 & 0.01 & 0.005 \\
\hline $\mathrm{O}_{2}$ & $\mu \mathrm{g} / \mathrm{L}$ & 100 & $50 \sim 100$ & $20 \sim 50$ & 2 & 1 \\
\hline
\end{tabular}

2 억 4천만불에서 2008 년까지 매년 평균 $4.3 \%$ 증가할 것으로 분석되고 있어 상대적으로 매우 좋은 시장으로 평가받고 있는 데 이러한 수요증가는 무엇보다도 자동차용 배기가스 캐니스 터(canisters)와 산업용으로 수은 제거를 위한 제품을 생산하는 데 사용이 증가하기 때문인 것으로 분석하고 있다.

한편 반도체의 집적도의 항상 등 산업기술의 고도화와 정밀 화로 인해 주변 요소기술들의 발전속도가 가속화되고 있는데, 이와 관련된 가장 중요한 기술적 요구사항이 바로 세척액으로 사용되는 물의 순도를 향상시키는 공정이다. 초순수란 단어는 이러한 시대적 요구에 의해 자연발생된 단어라 할 수 있으며, 초순수의 정의는 일반적으로 $17 \sim 18 \mathrm{M} \Omega$ 정도의 전기저항을 가진 물리화학적으로 화합물질 및 합성물질 등이 거의 존재하 지 않는 고도의 순수상태를 말하고 있다. 물이 높은 전기저항 을 가지기 위해서는 물에 존재하는 전기전도를 가능하게 하는 모든 미세입자뿐만 아니라 물에 이온상태로 존재하는 각종 염 을 제거해야 하며 그 제거수준은 수 $\mathrm{ppb}$ 이하로 유지해야만 가능한 것이다. 최근에는 반도체의 집적도가 향상됨에 따라 물 에 용존해 있는 기체, 예컨대 산소, 암모니아, 이산화탄소 등 의 농도도 낮추어야만 반도체 웨이퍼 등의 미세한 산화를 방 지할 수 있는 것으로 알려져 있다. Table 3에 반도체 산업에서 필요한 요구수질 항목을 나타내었다 [29].

\subsection{2. 세계 시장동향}

2006년 세계 각국의 활성탄소 수출입 현황을 살펴보면, 총 9십 2만 톤/년 이상이 거래된 것으로 나타나고 있다 [30]. 그 중 90 년대 이후 급속한 경제성장과 더불어 값싼 원자재와 노 동력을 바탕으로 한 중국의 교역량이 전 세계의 $27 \%$ 를 차지
함으로써 세계 최대의 교역국가가 되었으며, 미국과 일본이 각 각 $13 \%$ 와 $10 \%$ 로 뒤를 이었고, 이들 3 개국이 활성탄소 시장 중 $51 \%$ 를 선점하고 있다.

활성탄소의 세계 생산량은 2000년 말 1 백만 톤/년 이상으로 추정되며 최고 생산자는 미국과 유럽이지만 90 년대 말 이후 중국의 성장세가 두드러지고 있다. 활성탄소 시장은 소수의 회 사에 의해서 지배되고, Calgon 및 Norit가 세계 최대생산기업 이며 Calgon은 2000년에 총 2십만 톤년의 생산능력을 가졌고 Norit는 116,000 톤/년을 생산해내고 있다. 이 수치는 세계 생 산능력의 $32 \%$ 를 차지하며 Mead Westvaco 는 5 만 톤/년의 생 산능력을 가졌고, CECA과 Sutcliffe-Speakman은 각각 2만 톤 년을 생산하며 아시아 지역에서는 일본의 Kurarey Chemical 이 3만 5천 톤년으로 가장 큰 생산능력을 가지고 있으며, 뒤 를 이어 중국의 북경 태평양 활성탄소와 신화 활성탄소가 약 3 만 톤/년을 생산하고 있다. 그러나 이 수치는 세계 여러 위치 에 새 공장이 설치되고 있기 때문에 가까운 미래에는 변할 것 이며 대표적인 예로 네덜란드의 Norit와 일본의 Kurarey Chemical 등은 중국이나 동남아시아 등으로 활발하게 진출하 고 있다. 다음 Table 4에 세계 활성탄소 수출입 현황을 나타내 었다 [30].

세계 활성탄소 시장은 매년 5.2\%씩 증가하여 2012년에는 그 요구량이 1.2 억만 톤에 이를 것으로 전망하고 있다. 미국과 일본 및 중국이 세계 시장의 절반을 차지하고 있으며 중국은 2012 년 까지 현 $15 \%$ 에서 $18 \%$ 로 증가하는데 반해, 미국과 일 본의 생산량은 줄어들 것으로 예측하고 있으며, 유럽 또한 활 성탄소 시장에서 중요한 위치를 차지하고 있다. 다음 Table 5 에 미국과 유럽 주요 활성탄소 제조사의 생산량을 나타내었다. 
Table 4. 세계 활성탄소 수·출입 현황(2006년 기준)

\begin{tabular}{|c|c|c|c|c|}
\hline 순위 & 국가별 & 수입량(MT) & 수출량(MT) & 계(MT) \\
\hline 1 & 중 국 & 7,595 & 242,368 & 249,963 \\
\hline 2 & 미 국 & 67,585 & 56,415 & 124,000 \\
\hline 3 & 일 본 & 87,320 & 9,337 & 96,657 \\
\hline 4 & 네덜란드 & 27,594 & 32,175 & 59,769 \\
\hline 5 & 프랑스 & 27,167 & 15,598 & 42,765 \\
\hline 6 & 독 일 & 29,160 & 12,665 & 41,825 \\
\hline 7 & 이탈리아 & 34,207 & 6,964 & 41,175 \\
\hline 8 & 영 국 & 23,392 & 16,666 & 40,058 \\
\hline 9 & 한 국 & 38,300 & 217 & 38,517 \\
\hline 10 & 필리핀 & 589 & 34,421 & 35,010 \\
\hline 11 & 그 외 14 개국 & 82,071 & 71,858 & 155,403 \\
\hline 계 & 24개국 & 424,980 & 498,684 & 923,664 \\
\hline
\end{tabular}

Table 5. 미국과 유럽의 주요 업체별 활성탄소 생산량

\begin{tabular}{|c|c|c|c|}
\hline 순위 & 회사명 & 생산량 (ton) & 원료 \\
\hline \multicolumn{4}{|c|}{ 미국 } \\
\hline 1 & Calgon & 200,000 & 역청탄, 야자각 \\
\hline 2 & America Norit & 60,000 & 목재, 아탄 \\
\hline 3 & Mead Westvaco & 50,000 & 목재, 석탄 \\
\hline 4 & Royal Oak & 10,000 & 이탄 \\
\hline \multicolumn{4}{|c|}{ 유럽 } \\
\hline 1 & Norit (네덜란드) & 56,000 & 목재 \\
\hline 2 & $\begin{array}{c}\text { Sutcliffe Speakman } \\
\text { (영국) }\end{array}$ & 20,000 & 목탄, 석탄 \\
\hline 3 & CECA (프랑스) & 20,000 & 목재, 석탄, 야자각 \\
\hline 4 & 바이어 (독일) & 15,000 & 갈탄, 셀루로즈 \\
\hline 5 & PICA (프랑스) & 10,000 & 목재 \\
\hline 6 & 캠비론 (벨기에) & 10,000 & 역청탄 \\
\hline $7 \sim 11$ & $\begin{array}{c}\text { Norit (영국) 외4개 } \\
\text { 기업 }\end{array}$ & 27,000 & $\begin{array}{l}\text { 석탄, 야자각, } \\
\text { 갈탄, 목재 등 }\end{array}$ \\
\hline $12 \sim$ & 기타 10 개사 & 22,000 & \\
\hline
\end{tabular}

또한 Fig. 6에서 나타낸 것과 같이, 세계의 활성탄소 수요량은 환경 친화적인 생활환경을 위해서 그 요구량이 계속적으로 증 가하고 있으며, 이는 well-being의 시대적 요구에 따른 각국 정 부의 정책적 방향과도 상관성이 있는 것을 알 수 있다 [30].

입상활성탄소가 1980 년에는 49\%, 1991년 56\%, 2000년에는 $70 \%$ 까지 생산되고 있으며 역시 입상활성탄소의 재생능력이 성장하고 있고 많은 회사가 재생 서비스를 제공하고 있다. 활 성탄소는 생산자와 생산품에 의해서 크게 변하기 때문에 수많 은 등급과 가격 차이가 있지만, 지난 10 년간 관찰한 결과 1987

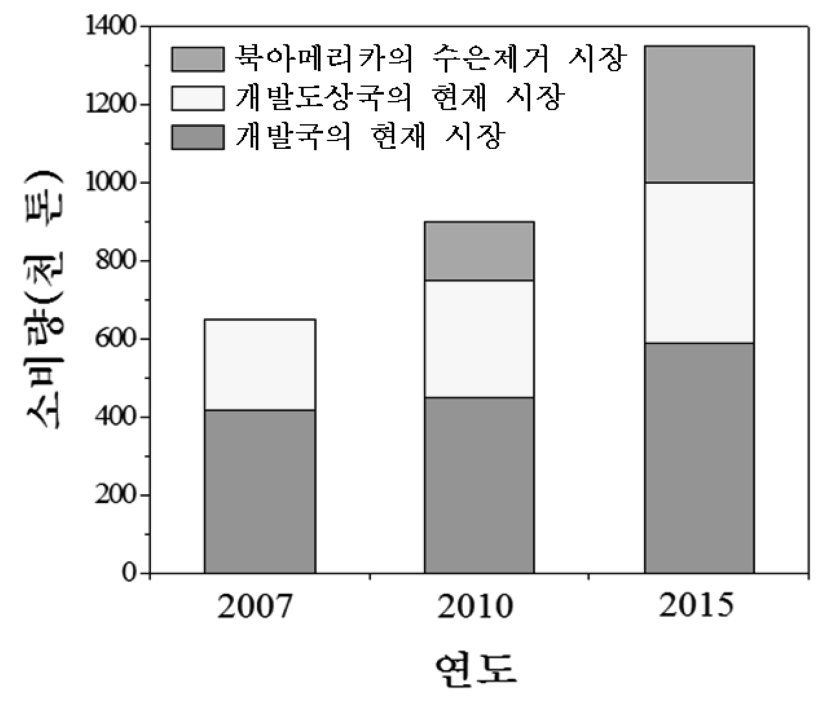

Fig. 6. 2010년과 2015년 활성탄소 소비 예상량.

년까지는 서서히 상승하였으나 그 이후는 더 눈에 띄게 증가 하였다. 미국에서 2000 년 평균값은 2.5 달러 $/ \mathrm{kg}$ 이었으며, 분말 상은 1.7 달러 $/ \mathrm{kg}$, 그리고 파쇄상은 3.3 달러 $/ \mathrm{kg}$ 이었다.

최근 가장 큰 시장으로 주목 받고 있는 중국의 경우에는 활 성탄소섬유 연구개발을 1970년대부터 시작하여 당시 원료 범 위는 PAN, 석탄산 알데하이드, 아스팔트 직물, 레이온 직물 등 이었지만, 연구개발 수준이 낮아 독립적인 공업부문을 형성하 지 못하였다. 본격적인 생산이 시작된 것은 1980년대 이후 들 어서였으나, 생산업체는 수십 개에 지나지 않았고 주로 수처 리 사업용으로만 사용되어 체계적인 생산방식을 갖추지 못하 고 있다. 그래서 중국의 활성탄소섬유 수요량은 2002년 2,000 톤, 2003년 2,300톤을 넘어서게 되었고, 단 2002년 생산량은 약 150 톤, 2003 년 생산량은 170 톤 수준에 불과해 전체 수요의 $90 \%$ 이상을 수입에 의존하고 있다. 수요 증가율은 매년 $15 \%$ 이상 으로 전망하고 있으며 수요 증가율이 매년 $15 \%$ 이상에 달해 향후 수입의존도는 보다 높아질 가능성이 있다고 판단된다.

2005년 탄소섬유의 시장점유율은 물량기준으로 Toray (24.8\%), Toho Tenax (23.4\%), Mitsubishi Rayon (10.8\%), Zoltek (8.5\%)의 순으로 일본기업이 강세이고, Toray, Toho, Zoltek, Cytec, Hexel 등의 세계시장 선두업체들은 신규투자를 통해 생산량을 늘려가며 수요증가에 대응하고 있다. 이러한 일 본의 Toray, Teijin, Asahi Kasei, Mitsubishi Rayon, Kurarey Chemical 등 세계 고기능 섬유시장을 석권하고 있는 대기업들 을 중심으로 범용 섬유에서 산업용 등 첨단소재부문의 투자를 지속적으로 확대하고 있다. 일본 후지경제의 '고기능 섬유시 장 실태조사 2008'에 따르면 일본의 고기능성 섬유시장은 일 상생활 용품에서 산업용으로 그 축을 점차 넓혀가고 있으며 일본 화학섬유 생산기업들은 세계시장에서 범용 저가 제품과 의 차별화를 도모하는 전략을 구사하고 있는 것을 알 수 있 다 $[31,32]$. 


\subsection{3. 국내 시장동향}

전국적으로 고도정수 처리시설로 인한 상수도의 수질개선 및 안정성 증대에 있어서 소비자에게 믿음과 기대에 부합하기 위한 핵심원료인 활성탄소 수급이 최대 관건으로 떠오르고 있 다. 최근 서울시는 영등포 정수장을 비롯하여 최근 기공식을 한 암사정수장 등 6 개 정수장에 고도정수시설이 완공되면 활 성탄소수급이 필수적인 요소가 될 것이다. 현재 활성탄소로 수 돗물처리를 하는 정수장은 수자원공사와 지방자치단체의 경우 수도권의 성남 외 12 곳, 울산시의 회야, 천상, 부산시의 명장, 화명, 덕산 등에서 사용되고 있는데 수자원공사의 경우 수도 권 지역만도 연 2 만 5 천톤이 필요할 것이라고 예상하고 있다. 그 중에서도 서울은 영등포 1,2 정수장(3,690톤), 3정수장 (2,337톤)을 비롯하여 강북( 10,440 톤), 암사(12,584톤), 광암 (2,929톤), 뚝섬(7,392톤), 구의(5,270톤) 등 총 4만 4천톤 정도 가 필요할 것으로 예상된다.

하지만 국내 활성탄소 생산기업은 15 개 업체에 불과하며, 해 외 원료생산지를 확보한 기업은 사실상 없는 실정이다. 국내 의 백석화학과 한독카본이 해외에 원산지를 확보하고 있는 것 이 유일한 반면, 일본은 전 세계 활성탄소 생산국가에 30 년 이 상의 계약을 맺고 독점적으로 가공하여 고가에 수출하고 있다. 활성탄소가 정수처리뿐만 아니라 담배필터, 방독면, 대기오염 방지시설, 폐수처리장, 원자력 등 그 용도가 날로 높아지고 있 는 반면에 국내 기업들은 아직 영세성을 면치 못하고 있으며, 환경부를 비롯한 정부나 지방자치단체는 이에 대한 대안마련 이 시급한 상태이다.

이에 정부는 2006년 2월 ‘물 산업 육성방안’을 마련한 데 이 어 2007년 6월 ‘물 산업 육성 5개년 추진계획'을 수립하는 등 정책적 지원을 강화하고 있다. 이에 따라 정부는 2008년부터 2012년까지 이 부문에서 총 9조 4,910억원을 투자 할 예정이 며, 이 중 9 조 3,500 억원 가량이 상하수도 미보급 지역 및 노 후시설 관망과 장래 물부족에 대비한 강변여과수, 해수담수화 등 대체 수원 개발투자 및 선진 정수처리 공정도입 등에 투자 될 예정으로 알려져 있다 [33].

특히 정부는 2009년 1월 미래 17 개 신 성장동력을 지정하 면서 고도정수처리 사업을 녹색기술산업 분야에 포함시켰으며, 고도 수처리와 관련한 녹색뉴딜 사업으로는 해외 물산업 진출, 해수담수화 상용화 기술개발, 하수 처리수 재이용 등이 있으 며, 3 개 사업분야에 총 6,880 억원을 투자할 예정이라고 발표 하였다. 수자원의 중요성을 인식하며 국민들에게 깨끗한 수질 의 수돗물을 공급하고자 하는 정부의 노력에 맞추어 그 핵심 이라 할 수 있는 활성탄소의 개발 및 성능향상을 도모해야 하 며, 그에 따른 고도정수처리 설치사업 또한 정부차원에서 준 비가 시작되고 있음을 알 수 있다 [34].

국내 물산업 시장은 빠르게 성장할 것으로 기대되는데, 그 이유는 정부의 물산업 육성의지, 국내의 용수부족 현상심화, 좋은 물에 대한 기대수준 상승 등이 예상되기 때문으로 판단 된다. 정부는 물산업 육성 추진계획을 통해 2005년 10.9 조 원 인 국내 물산업 시장을 10 년 내 20 조원 규모로 육성하겠다는
목표를 밝힌 바 있다. 만일 정부의 계획대로라면 국내 물산업 시장은 연평균 $6.3 \%$ 씩 성장할 것으로 예상된다. 또한 정부는 국내 2 개 이상의 기업을 세계 10 위권 기업으로 육성하겠다는 구체적인 목표도 제시하고 있기 때문에 그 기대치가 높다 [33]. 정부의 정책 방향이 특히 수처리 사업에 집중되고 있으며, 국 내 물산업 관련 업체도 글로벌 다국적 업체가 선점하고 있는 유틸리티 부문보다 수처리 시스템에 강점을 지니고 있는 만큼 수처리 사업을 영위하는 국내기업 중 두산중공업과 웅진케미 칼의 높은 수혜가 기대된다.

우리나라의 활성탄소시장을 살펴보면, 2006년 국내 총 수요 는 약 6 만 톤/년 정도로 추정되고 있고, 이 중에서 $63 \%$ 에 해 당하는 3 만 8천 톤년을 제품으로 수입함으로써 높은 해외 의 존도를 보이고 있다. 특히 수입물량 중 $74 \%$ 를 중국시장에 의 존하고 있기 때문에 중국시장의 변화에 따라 국내시장이 크게 영향을 받는다는 것은 국내 활성탄소 시장이 미약하다는 것을 의미한다. 활성탄소의 2005 년도 사업체수는 35 개소로, 2002 년 의 30 개소와 비교하여 $16.67 \%$ 증가하였고, 2004 년도의 33 개 소와 비교하여 $6.06 \%$ 증가하였다. 또한 활성탄소의 2005 년도 생산액은 663 억 원으로, 2002 년도의 512 억원에 비해 $29.47 \%$ 증가하였고, 2004년도의 607 억 원에 비해 $9.32 \%$ 증가하였다. 구체적으로 생산액의 연평균 성장률(CAGR)을 살펴보면, 2002 년부터 2005년까지의 CAGR은 $8.99 \%$, 2003년부터 2005년까 지 $\mathrm{CAGR}$ 은 $7.42 \%$ 의 성장률을 기록하여, 최근 3년 간의 연평 균 성장률은 2002년부터 2005년까지의 연평균 성장률보다 둔 화되었다.

활성탄소의 2005년도 출하액은 662억원으로, 2002년의 513 억원에 비해 $29.06 \%$ 증가하였고, 2004년도의 609 억원에 비해 $8.82 \%$ 증가하였으며 구체적으로 출하액의 CAGR을 살펴보면, 2002년부터 2005년까지 8.88\%, 2003년부터 2005년까지 $7.51 \%$ 의 성장률을 기록하여, 최근 3 년간의 $\mathrm{CAGR}$ 은 2002 년 부터 2005년까지의 연평균 성장률보다 둔화된 것을 알 수 있 다 [35]. Table 6에 국내 활성탄소의 수.출입 현황을 분석하였 으며, Fig. 7에 시장동향을 나타내었다.

일반적으로 활성탄소의 수요는 다음 10 년 동안 사용량이 증 가할 것으로 예측되고 있으며, 물처리와 공기정화 시장에서 환 경규제의 실행과 강화에 의해 성장되고 있다. 미래 활성탄소 에 대한 낙관적인 수요는 오염규제와 삶의 질을 증대하기 위 한 관심증가이며 이러한 개념에 따라 활성탄소의 사용을 요구 할 것이므로 연구자와 제조자는 다양한 품질과 다양한 형태의 수용에 충족하도록 준비해야 할 것이다. 또한, 새로운 활성탄 소의 개발과 새로운 원료개발뿐만 아니라 활성화방법도 다양 화해야 할 것이다.

우리나라의 활성탄소 수요량은 신탄을 기준으로 1980년대 후 반부터 연평균 20\%씩 계속 증가하고 있으며 2006년 현재 총 수요량은 약 6 만톤으로 일본 총 수요량 약 12 만 5 천톤의 $50 \%$ 까지 신장되었고, 2015년 한국의 추정 수요량은 15 만톤으로 일 본 추정 수요량 22 만톤의 $65 \%$ 수준까지 증가할 것으로 예상된 다. 고도 정수 처리용과 휘발성 유기화합물 흡착용으로 입상활 
Table 6. 국내 활성탄소 수·출입 현황(2006년 기준)

\begin{tabular}{|c|c|c|c|c|c|c|c|c|}
\hline & 구분 & 2000년 & 2001년 & 2002년 & 2003년 & 2004년 & 2005년 & 2006년 \\
\hline \multirow{2}{*}{ 수입 } & $\begin{array}{l}\text { 수량 } \\
\text { (MT) }\end{array}$ & 26,930 & 21,269 & 26,705 & 31,047 & 32,181 & 31,094 & 38,300 \\
\hline & $\begin{array}{c}\text { 금액 } \\
\text { (천불) }\end{array}$ & 30,410 & 24,807 & 30,339 & 36,585 & 38,924 & 38,563 & 43,088 \\
\hline \multirow{2}{*}{ 수출 } & $\begin{array}{l}\text { 수량 } \\
\text { (MT) }\end{array}$ & 184.3 & 202.4 & 269.3 & 509.6 & 565.7 & 135.2 & 217 \\
\hline & $\begin{array}{c}\text { 금액 } \\
\text { (천불) }\end{array}$ & 341 & 1,166 & 2,072 & 1,949 & 1,644 & 1,148 & 798 \\
\hline
\end{tabular}

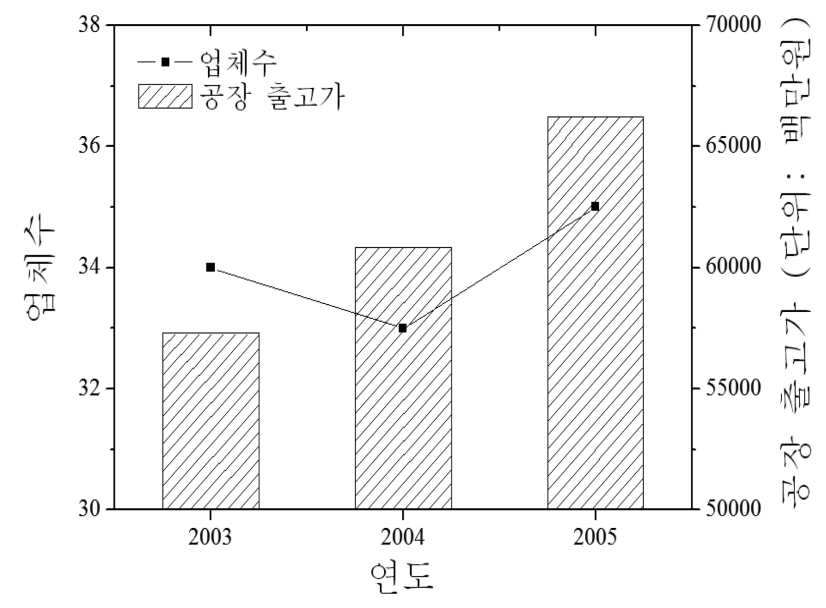

Fig. 7. 국내 활성탄소 시장동향 그래프.

성탄소의 국내 수요는 더욱 증가될 것으로 기대되는 반면에 분 말활성탄소의 수요는 거의 일정한 수준을 유지하고 있다.

그 밖에도 활성탄소섬유는 국내에는 지금까지 그 생산기반 이 전무한 상태여서 전량 수입에 의존하고 있는 실정이며 수 입량은 해마다 큰 폭으로 늘고 있는 추세였다. 미국의 대 한 국 수출액은 2000년도에 171만 7천불, 2001년도에 183만 5천 불, 2002년도에 230만 3천불에서 2003년에는 413만불로 금액 은 크지 않으나 지속적으로 증가하는 추세를 나타내고 있고, 특히 2003년은 2002년 대비 $79.4 \%$ 의 큰 폭의 증가율을 기록 하였다. 우리나라는 1990년대 말부터 중소기업과 학계의 활성 탄소섬유 기술연구가 활발히 진행되면서 핵심적인 생산 공정 기술을 보유하게 되었고, 이를 통해 연간 150 억원의 수입 대 체효과를 기대하고 있다.

\section{3. 결 론}

본 논문에서는 흡착능력 및 흡착속도가 우수할 뿐만 아니라 비표면적과 미세기공의 크기 및 구조를 그 사용목적에 따라 다양하게 변화를 줄 수 있는 극한소재로서의 활성탄소가 고도
정수처리 기술에 응용됨에 있어서의 그 중요성과 시장동향에 관하여 대략적으로 기술하였다.

최근 세계의 물부족 현상으로 인하여 수처리 사업의 중요성 이 부각되는 이 시점에서 활성탄소 처리기술은 수처리 분야에 서 그 활용범위가 확대되어 가고 있는 방법이며, 국내에서 최 근 대기오염뿐만 아니라 공공수역의 수질오염 방지를 위해 지 방자치단체가 운영하는 하/폐수종말처리시설, 폐기물 처리시 설 등에서 배출되는 물에 대해 수질 환경보전법 제 32 조 제 2 항의 규정에 의해 방류수 수질기준을 설정해 규제 하고 있기 때문에 각 기업체나 공장에서의 활성탄소의 수요는 계속해서 늘어날 것이다. 실제로 많은 수처리 공정에서 활성탄소처리가 적용되고 있으며, 활성탄소가 가지고 있는 뛰어난 흡착력을 이 용하여 맛, 냄새, 유기염소화합물, 합성세제 등 광범위한 물질 을 제거하거나 저감시키는 등 고효율 정수처리 기능을 수행하 고 있다.

그러나 활성탄소의 이러한 흡착성질을 유효하고 적절히 이 용하기 위해서는 사전에 제거 대상물질의 종류, 종류에 따른 처리효과 등과 관련한 충분한 조사와 실험을 실시할 필요성이 있다고 판단되며, 실제로 흡착속도와 흡착의 정도를 가늠할 수 있는 여러 흡착모델이 존재하지만 수질 내 오염물질의 다양성 과 분자구조의 상이성, 기타 변수 등의 영향으로 단순 예측범 위를 넘어서는 경우가 많이 있기 때문에 오염물질의 제거율을 나타내는 파과곡선, 활성탄소의 흡착능력 등과 관련한 충분한 사전조사와 연구를 통해 활성탄소의 종류, 처리순서, 설비의 규모, 방식 등을 비교, 검토하여 선정하여야 할 것이다.

또한 활성탄소를 제조하는 공법의 가장 큰 문제는 재생과 관련한 높은 운전비에 있으며, 초기에는 우수한 흡착력을 보 이지만 사용시간과 수질에 따라 급격히 흡착 성능이 저하되기 때문에 활성탄소 재생 및 교체주기가 잦아지고 이로 인한 추 가비용이 상당하므로 보다 경제적인 활성탄소도입을 위해서는 재생방식에 따른 손실을 최소화 하고 재생과정의 에너지 비용 을 절감시키며, 재생반복 횟수를 증가시키는 등의 효율적인 재 생시스템에 대한 기술을 개발하여야 할 것이다.

고도정수처리용 기능성 탄소재료에 대한 전반적인 기술축적 및 세계시장 개척이 가능할 것으로 예측되며, 구체적으로 고 비표면적 활성탄소의 개발, 수은선택형 관능기 도입을 위한 고 
부가가치 표면처리 기법개발, 원천 나노구조 탄소재료 합성 기 술개발에 따른 에너지, 정밀화학, 기능성 흡착제 등 관련 산업 분야로의 응용이 확대되어 소재와 부품에 대한 기술적 파급효 과를 창출할 수 있을 뿐만 아니라 향후 보다 엄격해지는 수질 환경오염에 대한 규제 및 요구에 대하여 효과적으로 대응할 수 있을 것이다.

또한 현재 늘어나는 활성탄소의 수요에 맞추어 위와 같이 활성탄소의 응용분야를 넓힐 뿐만 아니라 경제적인 제조공정 을 개발하며, 이와 같은 연구 속에서 특허 및 원천기술을 확 보해 나간다면 앞으로 더욱 각광을 받게 될 환경분야에서 우 리나라는 높은 금전적 및 환경 보호적 이익을 동시에 누릴 수 있을 것이라고 판단된다.

\section{References}

[1] Ministry of Environment, "Standards of Water Supply Facilities", Korea Water Work Association, 1997.

[2] Shannon, M. A.; Bohn, P. W.; Elimelech, M.; Georgiadis, J. G.; Mariñas, B. J.; Mayes, A. M. Nature 2008, 452, 301.

[3] Simpson, D. R. Water Res. 2008, 42, 2839.

[4] Lee. S. H.; Lee. S. H.; Jheong, W. H.; Kim, T. S.; Kim, Y. H. Mol. Cell. Toxicol. 2010, 6, 287.

[5] Kasuga, I.; Nakagaki, H.; Kurisu, F.; Furumai, H. Water Res. 2010, 44, 5039.

[6] Sánchez-Polo, M.; Rivera-Utrilla, J.; Méndez-Diaz, J. D.; Canonica, S.; von Gunten, U. Chemosphere 2007, 68, 1814.

[7] Ministry of Environment, "Standards and Specifications of Agent Materials for Drinking Water Treatment", No. 200792, Korea, 2007.

[8] Ministry of Health, Labour, and Welfare, "Standards of Japan Water Work Association", Japan Water Work Association, 2002.

[9] Bansal, R. C.; Goyal, M. "Activated Carbon Adsorption", Taylor \& Francis, Florida, 2005, 7.

[10] Park, S. J. "Principle and Applications of Carbon Materials", Daeyeong, Seoul, 2006, 560.

[11] Kim, B. J.; Park, S. J. J. Colloid Interface Sci. 2008, 325, 297.

[12] Yan, M.; Wang, D.; Ma, X.; Ni, J.; Zhang, H. Sep. Purif. Technol. 2010, 72, 263.

[13] Freedonia Group Inc., "World Activated Carbon Industry" www.reportlinker.com, 2010.

[14] Seo, M. K.; Park, S. H.; Kang, S. J.; Park, S. J. Carbon Lett. 2010, 10, 43.

[15] Kim, Y. H.; Park, S. J. Appl. Chem. Eng. 2010, 21, 183.

[16] Kalkan, Ç.; Yapsakli, K.; Mertoglu, B.; Tufan, D.; Saatci,
A. Desalination, 2010, 265, 266.

[17] Kang, S. J.; Kim, K. J.; Kim, M. S.; Kim, B. J.; Kim, S.; Roh, J. S.; Riu, D. H.; Park, S. J.; Seo, M. K.; Shul, Y. G.; An, K. H.; Yang, K. S.; Ryu, S. K.; Lee, G. W.; Lee, Y. S.; Lee, J. M.; Lee, C. H.; Lim, S. Y.; Lim, Y. S.; Jung, D. H.; Cho, K. Y.; Cho, D. H.; Chi, S. H.; Hong, I. P. "Handbook of Carbon Materials Applications", Daeyeong, Seoul, 2008, 619.

[18] Sing, K. S. W.; Everett, D. H.; Haul, R. A. W.; Moscou, L.; Pierotti, R. A.; Rouquérol, J.; Siemieniewska, T. Pure Appl. Chem. 1985, 57, 603.

[19] Wilson, K.; Yang, H.; Seo, C. W.; Marshall, W. E. Bioresource Technol. 2005, 97, 2266.

[20] Chen, J. M.; Wu, C. Y. Carbon 2001, 35, 4159.

[21] Frumkin, A. N. J. Electro. Chem. 1975, 64, 247.

[22] Meng, L. Y.; Cho, K. S.; Park, S. J. Carbon Lett. 2010, 11, 34.

[23] Song, X.; Liu, H.; Cheng, L.; Qu, Y. Desalination 2010 , $255,78$.

[24] Yin, C. Y.; Aroua, M. K.; Daud, W. M. A. W. Sep. Purif. Technol. 2007, 52, 403.

[25] Lee, S. Y.; Park, S. J. Int. J. Hydrogen Energy 2010, 35, 6757.

[26] Technical News "New Process Points Way Forward for Activated Carbon", Filtration and Separation, Frankfurt, 2010.

[27] LG Economic Research Institute and Samsung Economic Research Institute, "GWI 2008 Global Water Market", 2008.

[28] Maiga, H. 5th World Water Forum, Istanbul, Session 3.2.3, 2009.

[29] ASTM International, "Standard Guide for Ultra-Pure Water Used in the Electronics and Semiconductor Industries", ASTM D 5127-07, 2007.

[30] Roskill Information, "The Economics of Activated Carbon", 8th ed., UK, 2008.

[31] Korea Industrial Technology Evaluation and Planning, "Nano-fiber Materials", 2006.

[32] Kim, K. S.; Shim, Y. S.; Kim, B. J.; Meng, L. Y.; Lee, S. Y.; Park, S. J. Carbon Lett. 2010, 11, 235.

[33] Ministry of Environment, "Development Plan of Water Industry", Ministry of Environment, Korea, 2006.

[34] Ministry of Knowledge and Economy, "Developing New Growth Engines", Ministry of Knowledge and Economy, Korea, 2009.

[35] Korea National Statistical Office, "Statistical Survey Report of Mining and Manufacturing Industry", 2007. 